\title{
A Novel Ni-Free Zr-Based Bulk Metallic Glass with High Glass Forming Ability, Corrosion Resistance and Thermal Stability
}

\author{
Yu Luo, Yidong Jiang, Pei Zhang, Xin Wang, Haibo Ke and Pengcheng Zhang* (i)
}

\begin{abstract}
Zr-based Bulk metallic glasses exhibit incredible corrosion resistance and glass forming ability, however, these properties need further enhancement to meet the practical use. In this study, $\mathrm{Zr}_{63} \mathrm{Fe}_{2.5} \mathrm{Cu}_{23} \mathrm{Al}_{11.5}$, a new type of $\mathrm{Zr}$-based bulk metallic glass was fabricated. Potentiodynamic polarization techniques were used to measure the corrosion resistance of this alloy. Furthermore, crystallization behavior and kinetics of $\mathrm{Zr}_{63} \mathrm{Fe}_{2.5} \mathrm{Cu}_{23} \mathrm{Al}_{11.5}$ bulk metallic glass were investigated by using differential scanning calorimetry of non-isothermal model. Kissinger and Ozawa methods were used for calculating activation energies of crystallization and the mechanism of crystallization was analyzed by Johnson-Mehl-Avrami-Kolmogorow methods. The results suggest that this specified metallic glass system possesses a relatively high thermal stability and glass forming ability. Moreover, the crystallization procedure is mainly dominated by nucleation with an increasing rate. The study demonstrates that the slight composition adjustment of $\mathrm{Zr}-\mathrm{Fe}-\mathrm{Cu}-$ Al system bulk metallic glass can make a considerable contribution to higher glass forming and thermal stability as well as corrosion resistance.
\end{abstract}

Keywords: Zr-based BMG, Glass forming ability, Corrosion resistance, Thermal stability, Crystallization behavior

\section{Introduction}

Zr-based BMGs have drawn an increasing attention in recent years for their unique properties, such as high hardness, superior strength, excellent fracture toughness, enhanced elastic limit as well as improved corrosion resistance $[1,2]$. As strongly potential materials in biomedical industries, most of the Zr-based BMGs contain $\mathrm{Ni}$ or Be elements, which may cause allergies in human body [3]. Then $\mathrm{Zr}_{60} \mathrm{Fe}_{10} \mathrm{Cu}_{20} \mathrm{Al}_{10}$, a developed $\mathrm{Zr}$-based $\mathrm{Ni}$-free alloy is proposed for substitution, which possesses rather good glass forming ability (GFA) [4]. However, limited GFA is a major restriction in the application of BMGs as structural materials. Composition adjustment is therefore used to improve the GFA of BMGs [5, 6].

\footnotetext{
*Correspondence: 13981102769@163.com

Institute of Materials, China Academy of Engineering Physics, Jiangyou 621907, China
}

BMGs are essentially metastable, which inherently has the possibility to crystallize into a stable structure during thermal variation $[7,8]$. To build practical BMG parts, hot forming during super-cooled liquid region is often employed [9], the occurrence of partial crystallization may take place because of the thermal effect. Generally, the corrosion resistance of $\mathrm{Zr}$-based bulk metallic glasses (BMGs) with amorphous structure is 1-2 orders of magnitude higher than their crystalline counter parts, for the lacking of structural defects such as dislocations or grain boundaries in BMGs [10-13]. Thus, the building up of high performance BMG parts calls for a good thermal stability of BMGs to avoid the formation of crystalline phases. Therefore it is of great significance to recognize both the thermal characteristics and crystallization processes. The understanding of crystallization from kinetic aspect is important since the competition between nucleation and growth during the generating of crystalline phase can be quantified through the kinetic characters 
[14]. Non-isothermal method is widely applied with a fixed heating rate to reveal the crystallization behavior and thermal stability of bulk metallic glasses, particularly on Zr based BMGs, for its rapidity and efficiency [15]. An et al reported that the crystallization procedure of $\mathrm{Zr}_{62.5} \mathrm{Al}_{12.1} \mathrm{Cu}_{7.95} \mathrm{Ni}_{17.45}$ bulk metallic glass can be manifested into two stages. Rashidi et al. [16, 17] figured out the thermal stability and crystallization behavior of $\mathrm{Cu}_{47} \mathrm{Zr}_{47} \mathrm{Al}_{6}$ and $\left(\mathrm{Cu}_{47} \mathrm{Zr}_{47} \mathrm{Al}_{6}\right)_{99} \mathrm{Sn}_{1}$ bulk metallic glasses.

In this work, $\mathrm{Zr}_{63} \mathrm{Fe}_{2.5} \mathrm{Cu}_{23} \mathrm{Al}_{11.5}$ BMG, a new type of $\mathrm{Zr}-\mathrm{Fe}-\mathrm{Cu}-\mathrm{Al}$ system BMG with better glass forming ability and thermal stability, was prepared by suction-casting method. The corrosion resistance of the $\mathrm{Zr}_{63} \mathrm{Fe}_{2.5} \mathrm{Cu}_{23} \mathrm{Al}_{11.5}$ BMG was tested by potentiodynamic polarization techniques and then compared to $\mathrm{Zr}_{60} \mathrm{Fe}_{10} \mathrm{Cu}_{20} \mathrm{Al}_{10}$ BMG, 316L stainless steel (traditional structure material) as well as Ti-6Al-4V alloy (pitting resistant structural material). The thermal stability and crystallization kinetics of $\mathrm{Zr}_{63} \mathrm{Fe}_{2.5} \mathrm{Cu}_{23} \mathrm{Al}_{11.5}$ alloy were investigated by non-isothermal DSC methods. In particular, the crystallization kinetics were illuminated by studying the crystallization activation energy and crystallization mechanism.

\section{Experiments}

\subsection{Materials Preparation}

To avoid adding superfluous elements, the master ingots with nominal composition of $\mathrm{Zr}_{60} \mathrm{Fe}_{10} \mathrm{Cu}_{20} \mathrm{Al}_{10}$ (in at\%) and $\mathrm{Zr}_{63} \mathrm{Fe}_{2.5} \mathrm{Cu}_{23} \mathrm{Al}_{11.5}$ (in at\%) were fabricated by using arc-melting high-purity ingots of $\mathrm{Zr}$ (>99.9 wt\%), Fe (>99.99 wt\%), $\mathrm{Cu}(>99.99 \mathrm{wt} \%)$ and $\mathrm{Al}(99.99 \mathrm{wt} \%)$ for four times at least to ensure the chemical homogeneity. And cylindrical rods in diameters of 1-14 mm were fabricated under Ar atmosphere by suction-casting in watercooled copper molds.

\subsection{X-ray Diffraction Measurement}

The structural information of the as-cast rods were acquired by X-ray diffraction (XRD, Philips X'Pert Pro) using $\mathrm{Cu}-\mathrm{K} \alpha$ radiation with the determine range from $20^{\circ}$ to $90^{\circ}$. Before the measurement, the cylindrical rods were cut into pieces with the height of $1 \mathrm{~mm}$ and the cross section of the rods were grind by abrasive paper then polished on a polishing cloth with diamond polishing agent. The diffraction profiles were used to evaluate whether the as-cast rods were in an amorphous status.

\subsection{Thermal Behavior and Crystallization Kinetics Measurement}

The differential scanning calorimetry (DSC) tests were carried out within the temperature ranging from $300 \mathrm{~K}$ to $838 \mathrm{~K}$ under heating rates of $10,20,40$ and $80 \mathrm{~K} / \mathrm{min}$, respectively. The $\mathrm{Zr}_{63} \mathrm{Fe}_{2.5} \mathrm{Cu}_{23} \mathrm{Al}_{11.5}$ specimens tested in DSC were thinned before loading in the DSC cells to ensure the accuracy of the test.

\subsection{Corrosion Test}

The as-cast rods of $\mathrm{Zr}_{63} \mathrm{Fe}_{2.5} \mathrm{Cu}_{23} \mathrm{Al}_{11.5}$ alloy with diameters of 5 and $6 \mathrm{~mm}$ and the $\mathrm{Zr}_{60} \mathrm{Fe}_{10} \mathrm{Cu}_{20} \mathrm{Al}_{10}$ alloy with diameters of 1 and $3 \mathrm{~mm}$ were cut into pieces, and then fixed in epoxy resin and the untested side of specimens were linked with copper wires. These specimens were mechanically polished by an automated lapping machine, then sonicated in anhydrous alcohol for $600 \mathrm{~s}$ and sequentially dried by Ar flow. The corrosion behavior of $\mathrm{Zr}_{63} \mathrm{Fe}_{2.5} \mathrm{Cu}_{23} \mathrm{Al}_{11.5}$ samples were characterized by potentiodynamic polarization techniques which were conducted on an electrochemical workstation (AutoLab $302 \mathrm{~N}$, Metrohm). A three-electrode system was consist of a $\mathrm{Zr}_{63} \mathrm{Fe}_{2.5} \mathrm{Cu}_{23} \mathrm{Al}_{11.5}$ working electrode, a $4 \mathrm{~cm}^{2}$ Pt net as the counter electrode and a saturated calomel electrode as the reference electrode. The electrolyte was $\mathrm{NaCl}$ solution (3.5 $\mathrm{wt} \%$ ), and the electrolytic cell was commercial flat electrolytic cell. For comparison, the corrosion resistance of $\mathrm{Zr}_{60} \mathrm{Fe}_{10} \mathrm{Cu}_{20} \mathrm{Al}_{10}, 316 \mathrm{~L}$ stainless steel and Ti-6Al-4V alloy were tested as well.

\section{Results and Discussion}

\subsection{Glass Forming Abilities of $\mathrm{Zr}-\mathrm{Fe}-\mathrm{Cu}-\mathrm{Al}$ BMGs}

Figure 1 exhibits the XRD results of cylindrical rods in different diameters of $\mathrm{Zr}_{60} \mathrm{Cu}_{20} \mathrm{Fe}_{10} \mathrm{Al}_{10}$ and $\mathrm{Zr}_{63} \mathrm{Fe}_{2.5} \mathrm{Cu}_{23} \mathrm{Al}_{11.5}$ alloys. Due to the instrument we used in the present work, the critical diameter of $\mathrm{Zr}_{60} \mathrm{Cu}_{20} \mathrm{Fe}_{10} \mathrm{Al}_{10}$ BMG is $1 \mathrm{~mm}$ (Figure 1a), while the critical diameter of $\mathrm{Zr}_{63} \mathrm{Fe}_{2.5} \mathrm{Cu}_{23} \mathrm{Al}_{11.5}$ BMG is $5 \mathrm{~mm}$ (Figure $1 \mathrm{~b}$ ), which shows that the GFA of $\mathrm{Zr}_{63} \mathrm{Fe}_{2.5} \mathrm{Cu}_{23} \mathrm{Al}_{11.5}$ BMG is much better than that of $\mathrm{Zr}_{60} \mathrm{Cu}_{20} \mathrm{Fe}_{10} \mathrm{Al}_{10}$. The results indicate that $\mathrm{Zr}_{63} \mathrm{Fe}_{2.5} \mathrm{Cu}_{23} \mathrm{Al}_{11.5}$ BMG may have extensive application prospect compared with $\mathrm{Zr}_{60} \mathrm{Cu}_{20} \mathrm{Fe}_{10} \mathrm{Al}_{10}$ BMG in building practical parts.

\subsection{Corrosion Resistance of $\mathrm{Zr}_{63} \mathrm{Fe}_{2.5} \mathrm{Cu}_{23} \mathrm{Al}_{11.5} \mathrm{BMG}$}

$\mathrm{Zr}_{63} \mathrm{Fe}_{2.5} \mathrm{Cu}_{23} \mathrm{Al}_{11.5}, \mathrm{Zr}_{60} \mathrm{Fe}_{10} \mathrm{Cu}_{20} \mathrm{Al}_{10}$ BMGs, 316L stainless steel and $\mathrm{Ti}-6 \mathrm{Al}-4 \mathrm{~V}$ alloy in $3.5 \% \mathrm{NaCl}$ solution are illustrated in Figure 2, and corresponding corrosion data are listed in Table 1. It can be seen that all the Zr-based BMGs exhibit better corrosion performance than traditional structural materials (316L). With respect to $\mathrm{Zr}$ based BMGs with the same composition, the presence of a small amount of crystals leads to an order of magnitude increase in corrosion rate than that of amorphous phase. In addition, slightly composition adjustment can change the corrosion resistance of $\mathrm{Zr}$-based BMGs to some extent. With the decrease of the composition of Fe from 10 at.\% to 2.5 at.\% in $\mathrm{Zr}-\mathrm{Fe}-\mathrm{Cu}-\mathrm{Al}$ BMG, the corrosion potential $\left(E_{\text {corr }}\right)$ increases and the corrosion current 

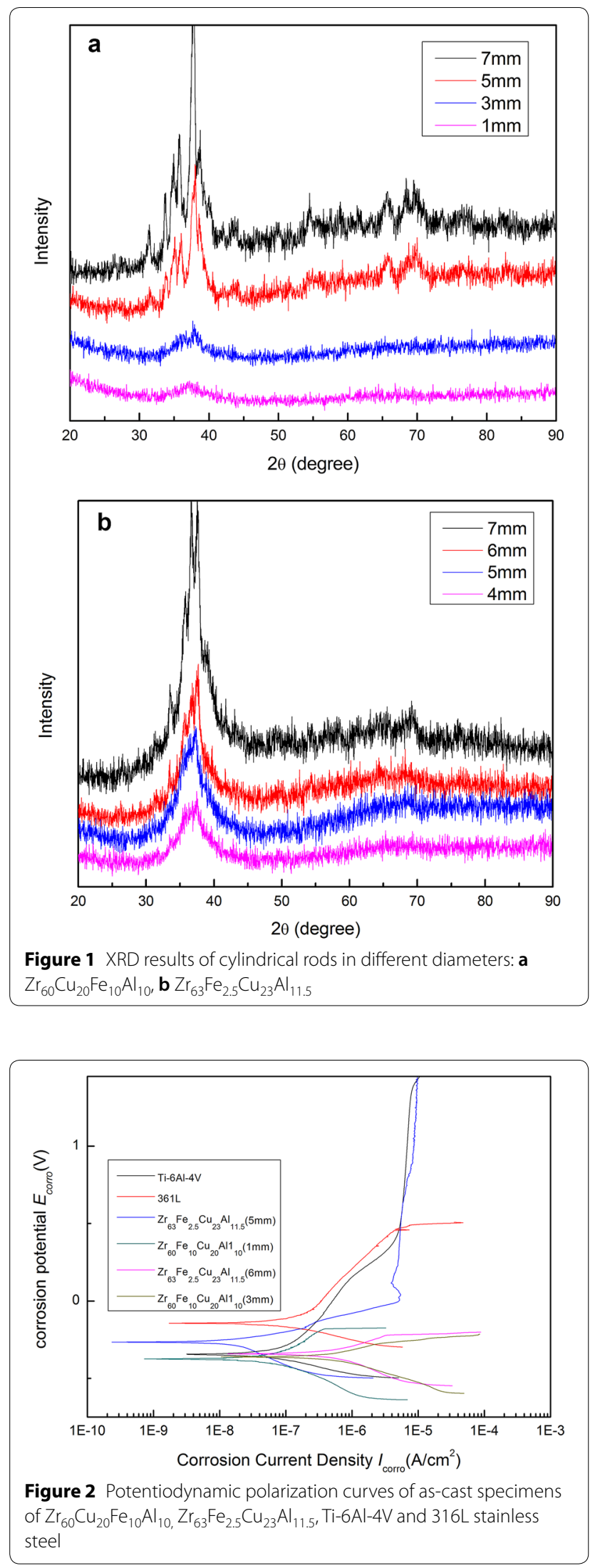

Table 1 Polarization data for $\mathrm{Zr}_{63} \mathrm{Fe}_{2.5} \mathrm{Cu}_{23} \mathrm{Al}_{11.5}$, $\mathrm{Zr}_{60} \mathrm{Fe}_{10} \mathrm{Cu}_{20} \mathrm{Al}_{10}, 316 \mathrm{~L}$ stainless steel and Ti-6Al-4V alloy

\begin{tabular}{lll}
\hline Alloy & $\boldsymbol{E}_{\text {corr }}(\mathbf{V})$ & $\boldsymbol{I}_{\text {corr }}(\mathbf{A})$ \\
\hline $316 \mathrm{~L}$ & -0.14 & $1.61 \times 10^{-7}$ \\
$\mathrm{Zr}_{63} \mathrm{Fe}_{2.5} \mathrm{Cu}_{23} \mathrm{Al}_{11.5}(5 \mathrm{~mm})$ & -0.26 & $2.03 \times 10^{-8}$ \\
$\mathrm{Zr}_{60} \mathrm{Fe}_{10} \mathrm{Cu}_{20} \mathrm{Al}_{10}(1 \mathrm{~mm})$ & -0.37 & $9.71 \times 10^{-8}$ \\
$\mathrm{Zr}_{63} \mathrm{Fe}_{2.5} \mathrm{Cu}_{23} \mathrm{Al}_{11.5}(6 \mathrm{~mm})$ & -0.34 & $5.36 \times 10^{-7}$ \\
$\mathrm{Zr}_{60} \mathrm{Fe}_{10} \mathrm{Cu}_{20} \mathrm{Al}_{10}(3 \mathrm{~mm})$ & -0.36 & $6.56 \times 10^{-7}$ \\
\hline
\end{tabular}

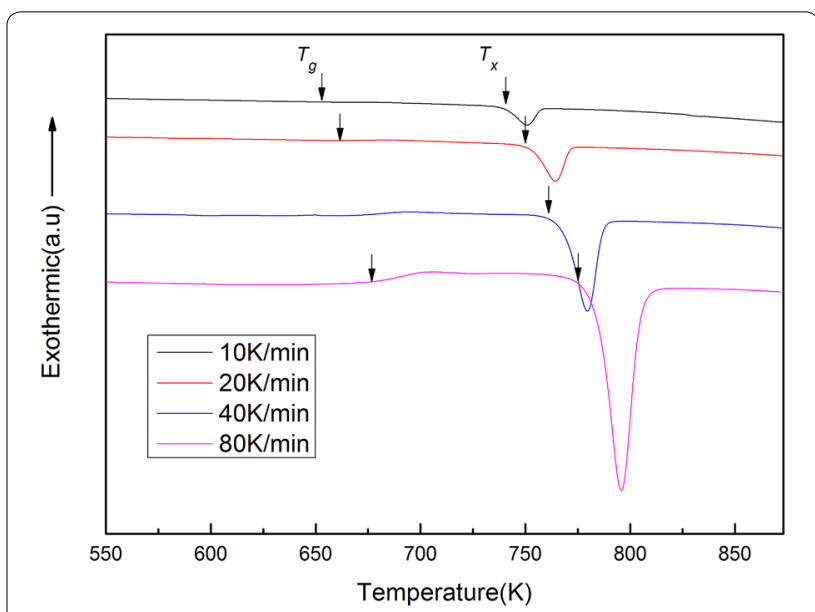

Figure 3 DSC curves of $\mathrm{Zr}_{63} \mathrm{Fe}_{2.5} \mathrm{Cu}_{23} \mathrm{Al}_{11.5}$ BMG with different heating rates

density $\left(I_{\text {corr }}\right)$ reduces $80 \%$, indicating that the corrosion resistance of the $\mathrm{Zr}-\mathrm{Fe}-\mathrm{Cu}-\mathrm{Al}$ BMGs is improved significantly. It is worth noting that the corrosion resistance of $\mathrm{Zr}_{63} \mathrm{Fe}_{2.5} \mathrm{Cu}_{23} \mathrm{Al}_{11.5}$ reaches the level of structural materials (Ti-6Al-4V alloy). It is mainly due to the reduction of amorphous material defects and the absence of grain boundaries.

\subsection{Thermal Stability of $\mathrm{Zr}_{63} \mathrm{Fe}_{2.5} \mathrm{Cu}_{23} \mathrm{Al}_{11.5}$ BMG}

Figure 3 shows typical non-isothermal DSC curves measured from the $\mathrm{Zr}_{63} \mathrm{Fe}_{2.5} \mathrm{Cu}_{23} \mathrm{Al}_{11.5}$ BMG under different heating rates. All the curves exhibit a single exothermic peak. The corresponding transition temperatures of inner structural, including glass transition temperature $\left(T_{g}\right)$, crystallization temperature $\left(T_{x}\right)$, and peak temperature $\left(T_{p}\right)$, are listed in Table 2 . It can be seen from Table 2 that with the increasing of heating rate, all the temperatures move to a higher value, which is characteristic of a dominant kinetic process. The curves show extended super-cooled liquid regions $\Delta T_{x}$ of width $76-86 \mathrm{~K}$, which are close to the reported $\Delta T_{x}$ of similar component BMGs [18] and higher than 
Table 2 Characteristic temperatures of $\mathrm{Zr}_{63} \mathrm{Fe}_{2.5} \mathrm{Cu}_{23} \mathrm{Al}_{11.5}$ BMG with different heating rates

\begin{tabular}{lllll}
\hline $\begin{array}{l}\text { Heating rate } \\
\text { (K/min) }\end{array}$ & $T_{g} \pm \mathbf{1}(\mathrm{K})$ & $T_{\boldsymbol{x}} \pm \mathbf{1}(\mathrm{K})$ & $\boldsymbol{T}_{\boldsymbol{p}} \pm \mathbf{1}(\mathrm{K})$ & $\boldsymbol{\Delta} T_{\boldsymbol{x}} \pm \mathbf{1}(\mathrm{K})$ \\
\hline 10 & 652 & 728740 & 750 & 76 \\
20 & 661 & 740752 & 764 & 79 \\
40 & 666 & 752761 & 779 & 86 \\
80 & 677 & 763775 & 795 & 86 \\
\hline
\end{tabular}

that of $\mathrm{Cu}-\mathrm{Zr}-\mathrm{Al}$ system BMGs [19], suggesting that the specified metallic glass system has a relatively high thermal stability.

The activation energies can be caculated by Kissinger equation as shown below [20]:

$$
\ln \left(\frac{T^{2}}{\theta}\right)=\frac{E}{R T}+\text { constant }
$$

where $T$ is the transition temperature $\left(T_{g}, T_{x}\right.$ and $\left.T_{p}\right)$ under a given heating rate $\theta, E$ is the activation energy and $R$ is the gas constant. The activation energy is determined by the slope and standard error of the linear fitted lines from the plot of $\ln \left(\frac{T^{2}}{\theta}\right)$ vs. $1 / T$. The values are calculated for the activation energies at glass transition temperature $\left(E_{g}\right)$, beginning of crystallization $\left(E_{x}\right)$ and crystallization peak $\left(E_{p}\right)$ as $301.4 \pm 16.5,256.91 \pm 8.6$ and $216.15 \pm 2.7 \mathrm{~kJ} / \mathrm{mol}$, respectively (Figure $4 \mathrm{a}$ ).

$E$ can also be calculated by Ozawa equation, which is shown below [21]:

$$
\ln \theta=-1.0561 \frac{E}{R T}+\text { constant, }
$$

where $\theta$ is the heating rate, $T$ is the specific temperature $\left(T_{g}, T_{x}\right.$ and $\left.T_{p}\right), E$ is the activation energy and $R$ is the gas constant. From the slopes and standard errors of the linear fitted lines (a plot of $\ln \theta$ against 1/T), the activation energies were estimated as $285.90 \pm 13.5,256.07 \pm 3.9$, $217.74 \pm 2.0 \mathrm{~kJ} / \mathrm{mol}$ for $T_{g}, T_{x}, T_{p}$, respectively (Figure $4 \mathrm{~b}$ ).

Kissinger and Ozawa methods are the most commonly used ways of calculating non-isothermal kinetic like crystallization activation energy $E$ or Avrami exponent $n$. As expected, the activation energies obtained by the two methods are close thereby indicating a good coherence.

Generally, $E_{g}$ represents the energy barrier of the structural transformation from the glassy structure to super-cooled liquid region, while $E_{x}$ gives information about the difficulty for the transition from the super-cooled liquid to the crystalline phase [22]. From Table 3, the $E_{g}$ value is higher than the $E_{x}$, which means that the energy barrier for glass transition is higher
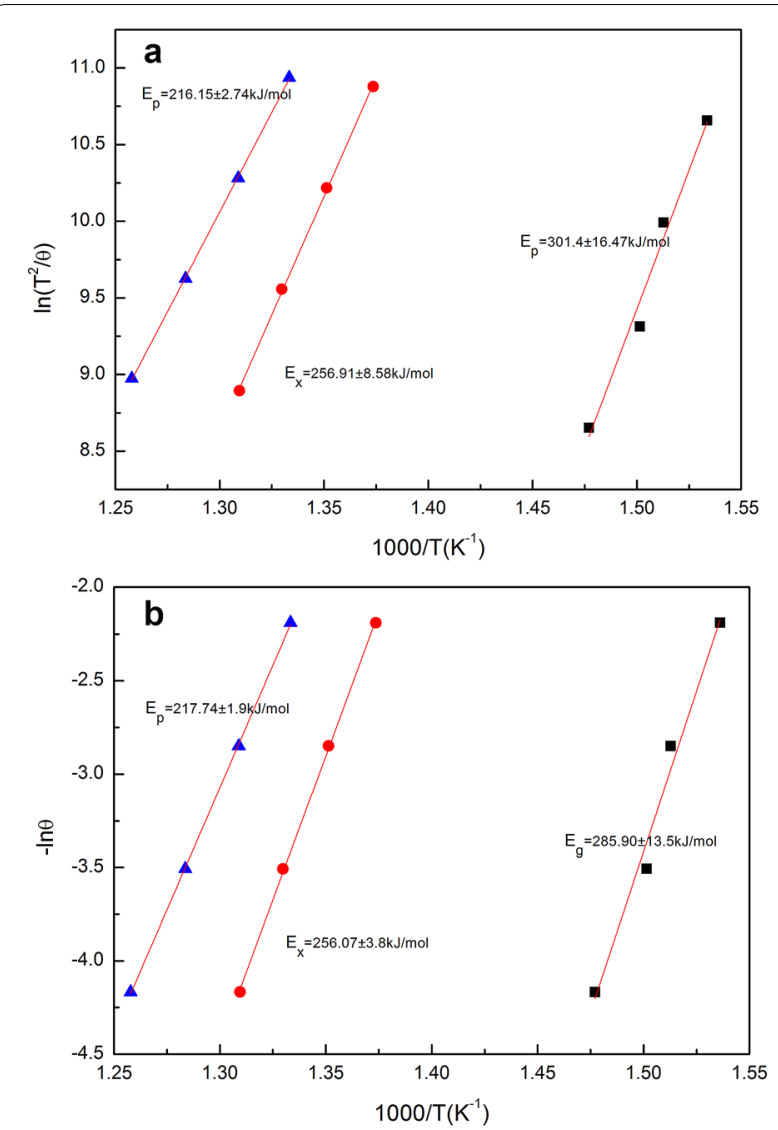

Figure 4 Determined activation energies $\left(E_{q^{\prime}} E_{x^{\prime}} E_{p}\right)$ by Kissinger and Ozawa methods of $\mathrm{Zr}_{63} \mathrm{Fe}_{2.5} \mathrm{Cu}_{23} \mathrm{Al}_{11.5} \mathrm{BMG}$

than that at starting point of crystallization. The thermal stability of BMGs can be evaluated by comparing the activation energies, namely the higher the activation energy, the harder the crystallization proceeds. Compared with our previous work on $\mathrm{Zr}_{60} \mathrm{Cu}_{20} \mathrm{Fe}_{10} \mathrm{Al}_{10}$ BMG, the $E_{g}$ and $E_{x}$ of $\mathrm{Zr}_{63} \mathrm{Fe}_{2.5} \mathrm{Cu}_{23} \mathrm{Al}_{11.5}$ BMG are higher than those of $\mathrm{Zr}_{60} \mathrm{Cu}_{20} \mathrm{Fe}_{10} \mathrm{Al}_{10}$, which indicates the $\mathrm{Zr}_{63} \mathrm{Fe}_{2.5} \mathrm{Cu}_{23} \mathrm{Al}_{11.5}$ BMG has a better thermal stability than $\mathrm{Zr}_{60} \mathrm{Cu}_{20} \mathrm{Fe}_{10} \mathrm{Al}_{10}$.

Table 3 The activation energy values $\left(\begin{array}{llll}E_{g} & E_{x} & E_{p}\end{array}\right)$ of $\mathrm{Zr}_{63} \mathrm{Fe}_{2.5} \mathrm{Cu}_{23} \mathrm{Al}_{11.5}$ and $\mathrm{Zr}_{60} \mathrm{Cu}_{20} \mathrm{Fe}_{10} \mathrm{Al}_{10} \mathrm{BMGs}$ calculated by Kissinger and Ozawa methods

\begin{tabular}{lrrr}
\hline & $\boldsymbol{E}_{\boldsymbol{g}}(\mathbf{k J} / \mathbf{m o l})$ & $\boldsymbol{E}_{\boldsymbol{x}}(\mathbf{k J} / \mathbf{m o l})$ & $\boldsymbol{E}_{\boldsymbol{p}}(\mathbf{k J} / \mathbf{m o l})$ \\
\hline $\mathrm{Zr}_{63} \mathrm{Fe}_{2.5} \mathrm{Cu}_{23} \mathrm{Al}_{11.5}$ (Kissinger) & $301.40 \pm 16.5$ & $256.91 \pm 8.6$ & $216.15 \pm 2.7$ \\
$\mathrm{Zr}_{63} \mathrm{Fe}_{2.5} \mathrm{Cu}_{23} \mathrm{Al}_{11.5}$ (Ozawa) & $285.90 \pm 13.5$ & $256.07 \pm 3.9$ & $217.74 \pm 2.0$ \\
$\mathrm{Zr}_{60} \mathrm{Cu}_{20} \mathrm{Fe}_{10} \mathrm{Al}_{10}$ (Kissinger) & $266.7 \pm 21.3$ & $240.9 \pm 6.4$ & $242.3 \pm 9.4$ \\
$\mathrm{Zr}_{60} \mathrm{Cu}_{20} \mathrm{Fe}_{10} \mathrm{Al}_{10}$ (Ozawa) & $277.9 \pm 21.3$ & $241.2 \pm 6.0$ & $242.7 \pm 8.7$ \\
\hline
\end{tabular}




\subsection{Non-isothermal Crystallization Kinetics of $\mathrm{Zr}_{63} \mathrm{Fe}_{2.5} \mathrm{Cu}_{23} \mathrm{Al}_{11.5} \mathrm{BMG}$}

\subsubsection{Local Activation Energy (LAE)}

Examining the crystallization peaks in the DSC curves obtained under different heating rates (Figure 5a) shows that the range of the crystallization peaks became larger as the heating rate increased. Figure 5 a displays a partial DSC curve of $\mathrm{Zr}_{63} \mathrm{Fe}_{2.5} \mathrm{Cu}_{23} \mathrm{Al}_{11.5}$ BMG at different heating rates. The crystal volume fraction $x$ at any temperature is $x=S t / S$, where $S$ is the total area of the crystallization peak between the temperature at which crystallization starts and the temperature at which crystallization is ended, and $S t$ is the portion of the crystallization peak up to the temperature $\mathrm{T}$ area. Thus, Figure $5 \mathrm{~b}$ shows the volume fraction of crystallization $(x)$ at different temperatures, which is a typical S-shape and consistent with other developed amorphous alloys [23, 24].

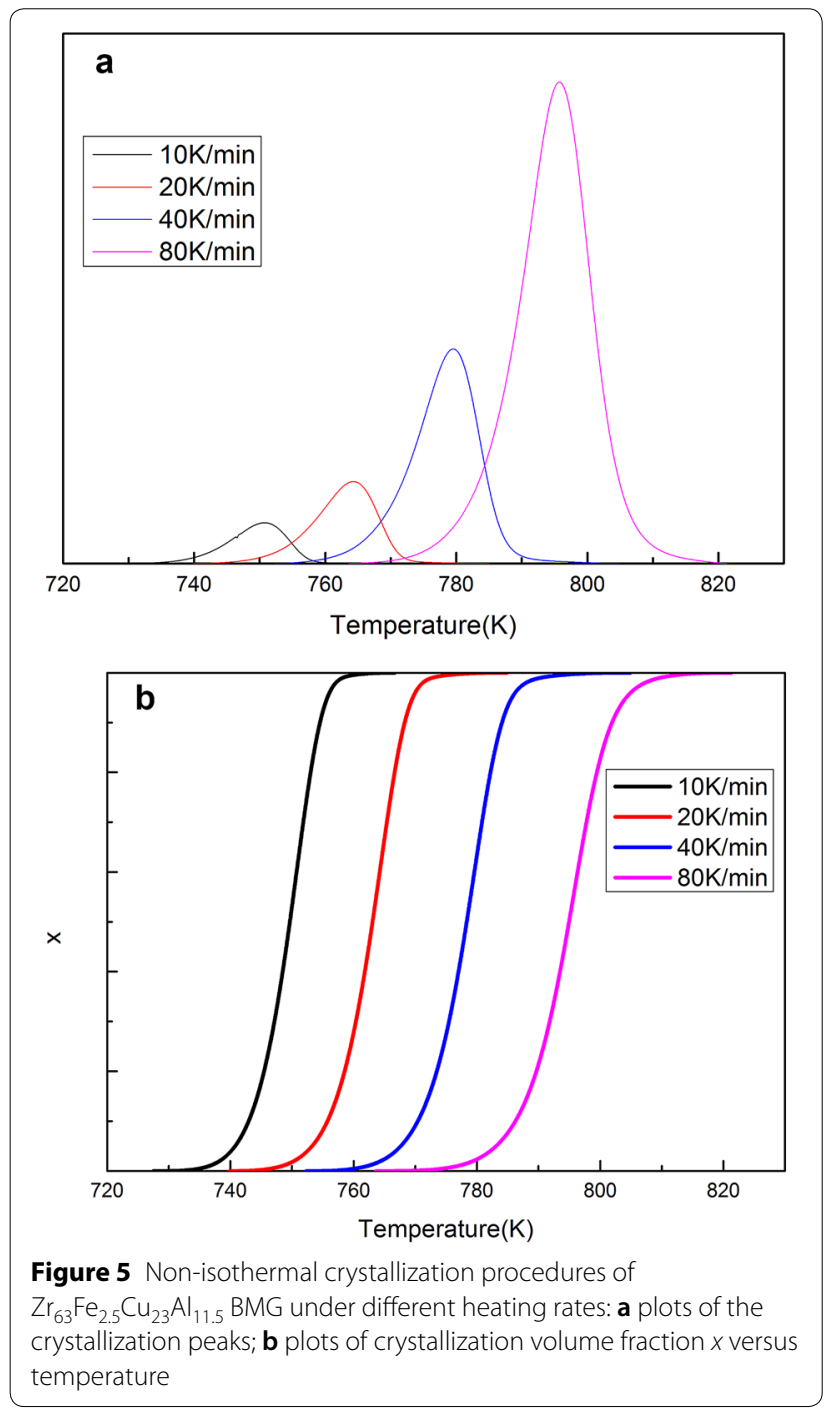

Since the local activation energy (LAE) changes in different stages of crystallization procedure [25], the change in LAE with the crystallization volume fraction can be determined. Figure 6a plots the linear fitted relationship between $\ln (\theta)$ and $1000 / T$ with different crystallization volume fractions $(x)$ from non to all, where the evolution of the LAE calculated by the Ozawa method was expressed in Figure 6b.

$E_{c}(x)$ shows a downward trend with the increase of $x$, indicating that the energy barrier reduces during the crystallization reaction, makes it more available for the crystallization proceeds. At the starting stage $(x<0.1)$, the activation energy decreases rapidly as well as the increasing of $x$, indicating that the process is dominated by nucleation, and the nucleation needs to overcome the high energy barrier. As the crystallization proceeds $(0.1<$ $x<0.9)$, the curve shows a gradual decreasing tendency due to structural relaxation of the amorphous structure around the crystalline phase. In the ending stage, the
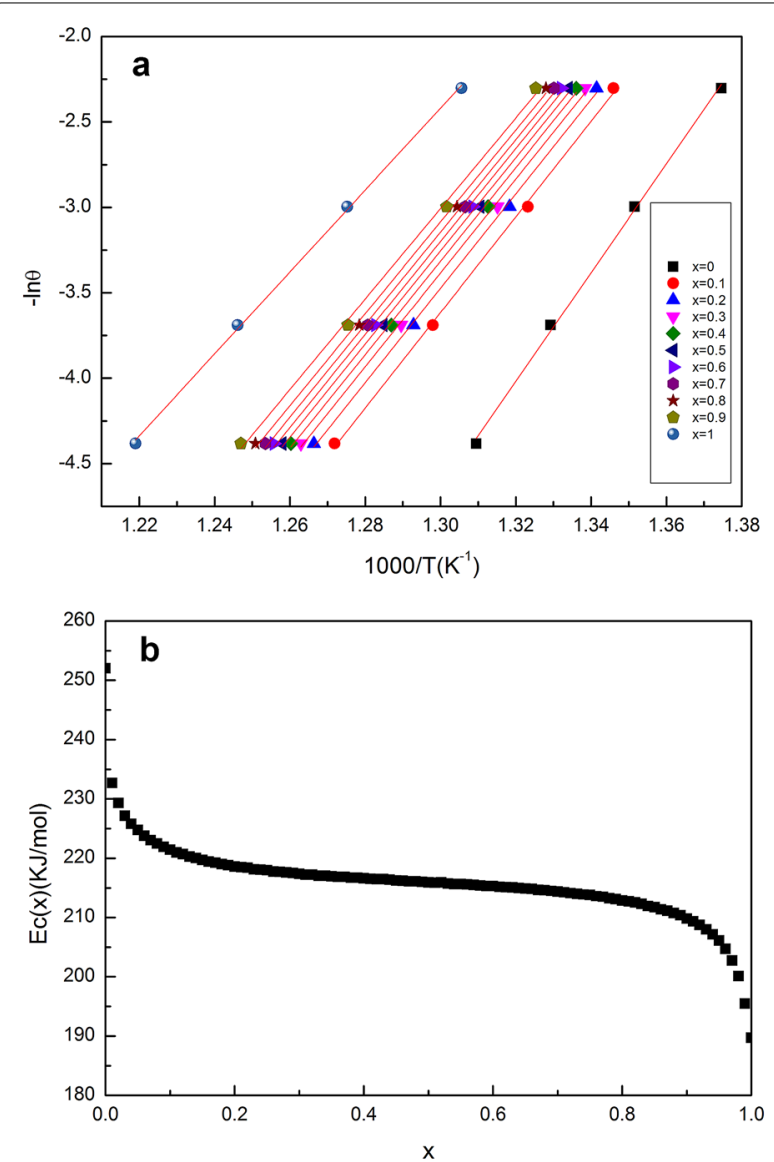

Figure 6 Non-isothermal crystallization of $\mathrm{Zr}_{63} \mathrm{Fe}_{2.5} \mathrm{Cu}_{23} \mathrm{Al}{ }_{11.5} \mathrm{BMG}$ under different heating rates: a plots of $\operatorname{In}(\theta)$ vs. 1000/T with different volume fractions of crystallization; $\mathbf{b}$ plot of local activation energy as a function of $x$ based on the Ozawa-Flynn-Wall method 
activation energy drops sharply, which reveals the crystallization procedure is dominated by growth.

\subsubsection{Kinetic Parameter-Evolution of Local Avrami Exponent}

To figure out the competition between the nucleation and growth, the crystallization of $\mathrm{Zr}_{63} \mathrm{Fe}_{2.5} \mathrm{Cu}_{23} \mathrm{Al}_{11.5}$ amorphous alloy was determined based on Johnson-MehlAvrami-Kolmogorow (JMAK) model:

$$
x=1-\exp \left(-k t^{n}\right),
$$

where $x$ and $n$ are crystallization volume fraction and Avrami exponent [26], $k$ is the rate constant related to temperature:

$$
k=A \exp \left(-\frac{E}{R T}\right)
$$

where $A$ and $E$ are the pre-exponential term and activation energy, $T$ represents the temperature, $R$ is the gas constant and. Figure 7a shows the JMAK plots of the data measured under various heating rates. As $n$ is variable along the entire crystallization procedure, the local Avrami exponent is employed to represent the corresponding dynamic characteristics as the equation below:

$$
n(x)=-\frac{R}{E c} \frac{\partial \ln [-\ln (1-x)]}{\partial\left(\frac{1}{T}\right)} .
$$

The JMAK equation is often employed to describe the isothermal crystallization behavior of BMGs originally, then it is extended to non-isothermal applications [27]. Therefore, in order to measure the Avrami exponent, first we need to plot $\ln [-\ln (1-x)]$ versus $1 / T$ as shown in Figure 7a, the Avrami exponent can be determined by the slopes of the curves as shown in Figure 7a. To understand the crystallization behavior of $\mathrm{Zr}_{63} \mathrm{Fe}_{2.5} \mathrm{Cu}_{23} \mathrm{Al}_{11.5} \mathrm{BMG}$, diffusion-controlled growth theory is often applied. According to this theory, the definition of Avrami exponent is used to determine the variation of nucleation and growth during crystallization procedure [28]. Considering the crystallization in the super-cooled liquid is diffusion-controlled, the Avrami exponent can be divided into the followings [29]: $n<1.5$ denotes the growth of crystals with an appreciable initial volume; $n=1.5$ indicates the growth dominates the crystallization procedure with no nucleation occurs; $1.5<n<2.5$ indicates the growth governs the crystallization procedure with a lower growth rate and a decreasing nucleation rate; $n=2.5$ reflects growth of crystals with a constant nucleation rate and $n>2.5$ indicates the growth of small crystals with an increasing nucleation rate.

Figure $7 \mathrm{~b}$ reveals the evolution of $n(x)$ depending on $x$ under different heating rates of $10,20,40,80 \mathrm{~K} /$
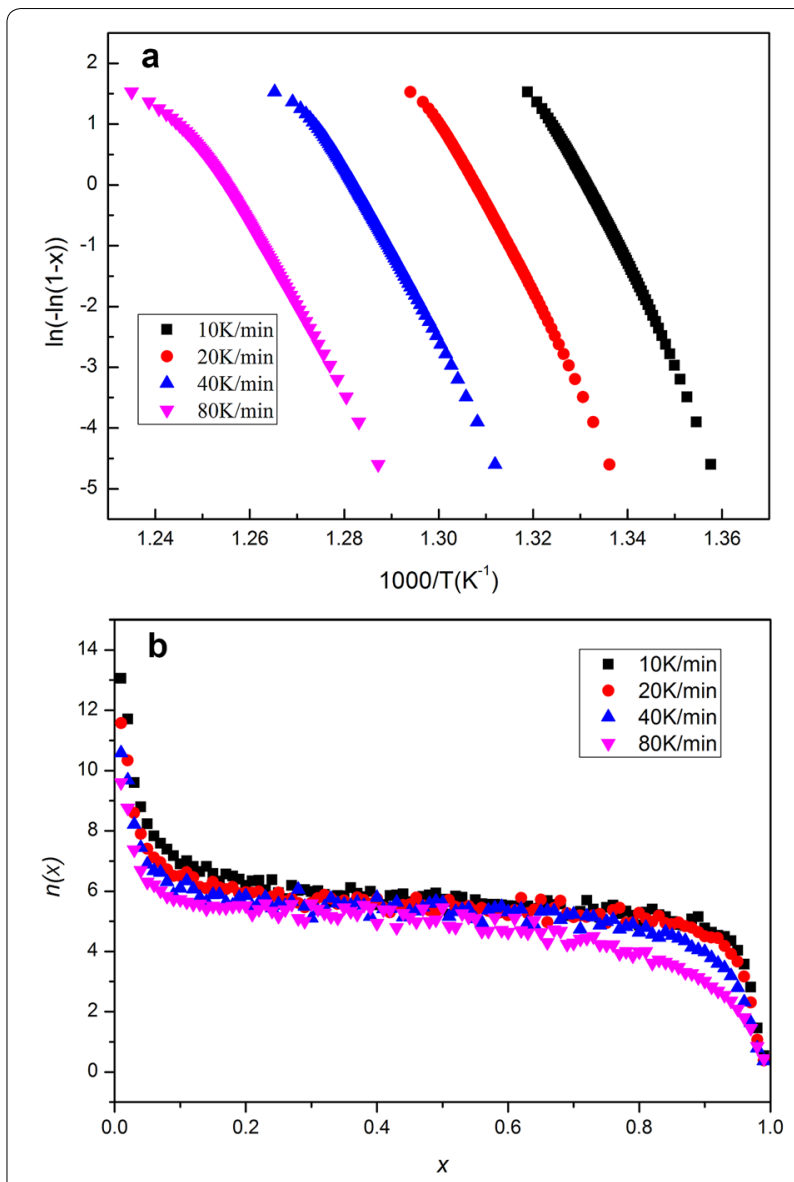

Figure 7 a $\ln [-\ln (1-x)]$ vs. 1000/T plots measured under different heating rates; $\mathbf{b}$ The plots of local Avrami exponent $n(x)$ as a function of crystallized fraction $x$ under heating rates of $10,20,40,80 \mathrm{~K} / \mathrm{min}$

min. $n(x)$ tends to decrease gradually, while the crystallization volume fraction increases. The variation of nucleation and growth rates during crystallization can be speculated by the variation of local Avrami exponent. In particular, the LAEX reduced from 12 to 0.8 under the heating rate of $80 \mathrm{~K} / \mathrm{min}$. From Figure $7 \mathrm{~b}$ it can be seen that if $x<0.9$ and $n(x)>2.5$, which refers the generating of nuclei although most of the matrix of $\mathrm{Zr}_{63} \mathrm{Fe}_{2.5} \mathrm{Cu}_{23} \mathrm{Al}_{11.5}$ BMG has been crystallized, and the nucleation rate increase rapidly from $0<x<0.1$ and became smooth from $0.1<x<0.9$. When $0.9<$ $x<0.98$ and $1.5<n(x)<2.5$, indicated that the rate of nucleation is reducing and growth rate increased. When $x>0.98$, the nucleation procedure tended to end. It can be inferred that the crystallization of $\mathrm{Zr}_{63} \mathrm{Fe}_{2.5} \mathrm{Cu}_{23} \mathrm{Al}_{11.5}$ BMG is mainly dominated by nucleation with a decreasing nucleation rate during most of crystallization procedure within $0<x<0.9$, after that growth took control and filled the rest of the amorphous matrix. 


\section{Conclusions}

In this work, a high glass forming ability Zr-based BMG with the composition of $\mathrm{Zr}_{63} \mathrm{Fe}_{2.5} \mathrm{Cu}_{23} \mathrm{Al}_{11.5}$ was fabricated. The BMG has excellent corrosion resistance, with the corrosion rate of $2.03 \times 10^{-8} \mathrm{~A} / \mathrm{cm}^{2}$ in a $3.5 \mathrm{wt} \%$ sodium chloride solution.

The overall crystallization activation energies of $\mathrm{Zr}_{63} \mathrm{Fe}_{2.5} \mathrm{Cu}_{23} \mathrm{Al}_{11.5}$ BMG, calculated by Kissinger and Ozawa methods, were $256.91 \pm 8.6$ and $256.07 \pm 3.9 \mathrm{~kJ} /$ mol, respectively, which denotes that the specified metallic glass system has a relatively high thermal stability. Then the crystallization mechanism was investigated by JMAK method. The results suggest that the crystallization procedure is mainly dominated by nucleation with decreasing nucleation rate.

\section{Acknowledgements}

The author would like to acknowledge Dr. Xue Liu and Dr. Jinru Luo from China Academy of Engineering Physics for helpful discussions.

\section{Authors' Contributions}

YL \&YJ did the corrosion tests, data analysis, writing, they contributed equally. XW and HK prepared the materials, PZ did the DSC \& XRD tests. PCZ revised the manuscript. All authors read and approved the final manuscript.

\section{Authors' Information}

Yu Luo, born in 1989, is currently an assistant research fellow at Institute of Materials, China Academy of Engineering Physics. He received his doctorate from China Academy of Engineering Physics, China, in 2020.

Yidong Jiang, born in 1992, is currently an assistant research fellow at Institute of Materials, China Academy of Engineering Physics. He received his doctorate from China Academy of Engineering Physics, China, in 2018.

Pei Zhang, born in 1987, is currently an associate research fellow at Institute of Materials, China Academy of Engineering Physics. He received his doctorate from Zhejiang University, China, in 2014.

Xin Wang, born in 1986, is currently an assistant research fellow at Institute of Materials, China Academy of Engineering Physics. He received his doctorate from China Academy of Engineering Physics, China, in 2017.

Haibo Ke, born in 1986, is currently an associate research fellow at Institute of Materials, China Academy of Engineering Physics. He received his doctorate from Chinese Academy of Science, China, in 2014.

Pengcheng Zhang, born in 1964, is currently a research fellow at Institute of Materials, China Academy of Engineering Physics. He received his doctorate from China Academy of Engineering Physics, China, in 2003

\section{Funding}

Supported by National Key R\&D Program of China (Grant No. 2017YFB0702404) and National Natural Science Foundation of China (Grant Nos. 51901212, 51701192).

\section{Competing Interests}

The authors declare no competing financial interests.

Received: 1 December 2019 Revised: 8 July 2020 Accepted: 20 August 2020

Published online: 11 September 2020

\section{Reference}

[1] W Johnson. Bulk glass-forming metallic alloys: Science and technology. MRS Bulletin, 1999, 24(10): 42-56.

[2] J Löffler. Bulk metallic glasses. Intermetallics, 2003, 11(6): 529.
[3] K Kalimo, L Mattila, H Kautiainen. Nickel allergy and orthodontic treatment. Journal of the European Academy of Dermatology and Venereology, 2004, 18(5): 543-545.

[4] Q S Zhang, D V Zhang, A Inoue. High glass-forming ability and unusual deformation behavior of new $\mathrm{Zr}$-Cu-Fe-Al bulk metallic glasses. Materials Science Forum, 2010, 654: 1042-1045.

[5] G Wang, L Feng, W Shen, et al. Effect of Mo content on glass forming ability and crystallization behavior of Fe-based alloy prepared by atmospheric plasma spraying. Results in Physics, 2019, 14: 102512.

[6] H Zong, L Bian, J Cheng, et al. Glass forming ability, thermal stability and elastic properties of Zr-Ti-Cu-Be-(Fe) bulk metallic glasses. Results in Physics, 2016, 6: 1157-1160.

[7] Z Q Chen, L Huang, F Wang, et al. Suppression of annealing-induced embrittlement in bulk metallic glass by surface crystalline coating. Materials \& Design, 2016, 109(5): 179-185.

[8] B Sarac, L Zhang, K Kosiba, et al. Towards the better: intrinsic property amelioration in bulk metallic glasses. Scientific Report, 2016, 6(1): 27271.

[9] S Sharma. Glassy carbon: A promising material for micro- and nanomanufacturing. Materials, 2018, 11(10): 1857.

[10] H Jazayeri, M Tahriri, M Razavi, et al. A current overview of materials and strategies for potential use in maxillofacial tissue regeneration. Materials Science \& Engineering: C, 2017, 70(1): 913-929.

[11] P Gostin, D Eigel, D Grell, et al. Stress-corrosion interactions in Zr-based bulk metallic glasses. Metal, 2015, 5(3):1262-1278.

[12] D Duraccio, M Faga, F Mussano. Biomaterials for dental implants: current and future trends. Journal of Materials Science, 2015, 50:4779-4812.

[13] D Miracle, O Senkov. A critical review of high entropy alloys and related concepts. Acta Materialia, 2017, 122: 448-511.

[14] D Kashchiev. Applications of the nucleation theorem. AlP Conference Proceedings, 2000, 534: 147.

[15] S Sarwat. Contamination in wet-ball milling. Powder Metallurgy, 2017, 60: 267-272.

[16] Y Luo, H Ke, R Zeng, et al. Crystallization behavior of Zr60Cu20Fe10Al10 amorphous alloy. Journal of Non-Crystalline Solids, 2020, 528: 119728.

[17] R Rashidi, M Malekan, R Gholamipour. Crystallization kinetics of Cu47Zr47Al6 and (Cu47Zr47Al6)99Sn1 bulk metallic glasses. Journal of NonCrystalline Solids, 2018, 498: 272-280.

[18] K Jin, J Löffler. Bulk metallic glass formation in Zr-Cu-Fe-Al alloys. Applied Physics Letters, 2005, 86: 241909.

[19] T Chung, S Jian, P Hsieh. The effect of Ag addition on the enhancement of the thermal and mechanical properties of CuZrAl bulk metallic glasses. Metals, 2016, 6: 216

[20] H E Kissinger. Reaction kinetics in differential thermal analysis. Analytical Chemistry, 1957, 29(11): 1702-1706

[21] T Ozawa. A new method of analyzing thermogravimetric data. Bulletin of the Chemical Society of Japan, 1965, 38: 1881.

[22] TWang, M Zeng, N Nollmann. Thermal stability and non-isothermal crystallization kinetics of Pd82Si18 amorphous ribbon. AlP Advances, 2017, 7: 065206.

[23] S Haratian, M Haddad-Sabzevar. Thermal stability and non-isothermal crystallization kinetics of $\mathrm{Ti}_{41.5} \mathrm{Cu}_{42.5} \mathrm{Ni}_{7.5} \mathrm{Zr}_{2.5} \mathrm{Hf}_{5} \mathrm{Si}_{1}$ bulk metallic glass. Journal of Non-Crystalline Solids, 2015, 429: 164-170.

[24] S Joshi, A Gkriniari, S Katakam. Dynamic crystallization during nonisothermal laser treatment of Fe-Si-B metallic glass. Journal of Physics D: Applied Physics, 2015, 48: 495-501.

[25] K Majhi, R Varma. Crystallization kinetic studies of CaBi2B2O7 glasses by non-isothermal methods. Journal of Materials Science, 2009, 44(2): 385-391.

[26] J W Christian. The theory of transformations in metals and alloys. 2nd Ed. New York: Pergamon, 1975.

[27] B Olga, A Reshetov, N Stefani, et al. Applicability of JMAK-type model for predicting microstructural evolution in nickel-based superalloys. Procedia Engineering, 2017, 207: 1105-1110.

[28] M Tomellini. Phase transformation kinetics of Voronoi cells in space tessellation governed by the Kolmogorov-Johnson-Mehl-Avrami model. Physucs Letter A, 2017, 381(12): 1067-1075.

[29] R Svobada. Crystallization kinetics in Se-Te glassy system-Effect of longterm material degradation. Thermochimica Acta, 2016, 639: 108-119. 